\title{
Sufism and the Contemporary Macedonian Society
}

\author{
Dragan Kostovski (MA) \\ University of Saints Cyril and Methodius, Skopje, Macedonia
}

Doi:10.19044/esj.2018.v14n20p185 URL:http://dx.doi.org/10.19044/esj.2018.v14n20p185

\begin{abstract}
Macedonian society was traditionally an area where Sufi movements were practicing their religious activities. As a result, it is a specific cultural area that has its influence in creating Sufism as a dominant religion within Ottoman Empire. Minding that historical circumstances, and also considering the area placed at the center of Balkan Peninsula, it has the qualities of multicultural characteristics that originates from centuries back due to the history of the area. In September 2017, a survey was conducted with the main goal of detecting and realizing the possible integrative traits and positive multicultural dimension of Sufism.
\end{abstract}

Keywords: Sufism, Multiculturalism, Macedonian society, Semi structural survey, Cultural coexistence, Social change

\section{Introduction}

In this paper, we will mention a brief overview of Sufism. Having in mind most of the western scholars working on this subject nowadays, finding a rather concise and pretty much less worded definition would be a next sociocultural challenge. Yet for this occasion, it is worth mentioning that what is a common practice in almost every explanatory review of Sufism is that this religious aspect of Islam is rather internal, and is a more mystical dimension of what we recon today as Islam religion (Beglerovic, 2004). Sufism is pragmatically connected with formative period of Islam religion and that is an historical fact (Karamustafa, 2007). History speaks that every time this religion is faced with harsh times that threatens its consistence, Sufism comes on the scene making things right again. Sufism is directed towards ethical proficiency of the followers. Thus, its teaching is dedicated towards social and individual serenity: teaching people to fight their never ending desires by achieving internal equilibrium and also teaching people to be kind among each other as all of what is created on this world is a divine creation having a divine purpose. The most profound ideal for every Sufi is divine love, love of God, and love of every creation since it is a divine creation. Every single script of a Sufi says about this ideal. There are no nations, no colors, considering humans; 
there are just men and women. By the way, this love principle doesn't stops here but incorporates everything in and on this world as a divine creation having a divine place in a divine plane that humans do not necessary understand. It is good to mention that what nowadays Wahhabism understands as a Jihad is a pan Muslim movement to fight against others, the nonbelievers.

What Sufis understand under Jihad is a bit different. It is a struggle within every man and woman, within themselves, with their worst enemy as stated by Muhammad, whit their soul. It is, therefore, a struggle with the soul's never-ending desires. This struggle within is the Jihad that Sufis is teaching about.

\section{I.}

Inside the territory of the Republic of Macedonia, in a rather isolated ambient, there are two prominent Tariqas: Bektashi Tarika in Debar area, and Alawi Tarika in Struga area. With an intention based on a detailed acquaintance with these Tariqas on the territory of Republic of Macedonia, a semi structural field survey that incorporated target group was conducted. This group consists of members of Islamic society inside the Republic of Macedonia, members of Islamic intellectual society, and members of Tariqas.

Having in mind the nature of the problem at this point, which is in essence a socially isolated groups, are not often present in everyday social life. As a result, a methodological frame in gathering raw data was used in a semi structural in-depth survey. The primary advantage of in-depth interviews is that they provide much more detailed information than what is available through other data collection methods, such as surveys (Boyce, 2006).

A common situation of group answer was notable to be praxis during most of the interviews. Therefore, measures were taken to isolate the interviewed contestants. In essence, every single contestant was conducted under three groups of a total of twenty one questions which was all centered around Sufism and euro integration processes.

The general atmosphere during all the interviews was relaxed and the interviewees were given the time for comfort and ease while answering the questions. Some of the interviews were performed inside religious institutions with a slight difficulty considering the curiosity of the crowd. Similarities occurred inside the educational institutions where interviews were conducted with academic society representatives. Hence, students have shown a particular interest considering the subject of the survey.

Nevertheless, the overall atmosphere was at the highest level of professionalism and every one of the contestant gave their best of effort to contribute at the final result. Most of the records given were recorded by writing down on paper and only some were tape recorded when interviewee gave allowance. 
The questions that were included in the interview, questions that frames the conversation with the interviewees, were a total of twenty one. Therefore, as we progress, an example of the questions that compose the interview would be given.

Among these twenty one question covered was a thematic area that has three aspects. Question numbered with 1, 2, 3, 4, and 5 involve the relation between Islamic society and Tariqas within Macedonian society. This thematic aspect has an expectation that interviewees will come up with a certain view on the situation of the Tariqas inside the Macedonian society. Having in mind the structure of the interviewees, they are divided into three groups: representatives of Islamic society are on the one side, on the other side are representatives of Tariqas, and in the middle are representatives of academic society. What was expected here was to provide certain deviations in attitudes considering the answering questions. Nevertheless, after summarizing the answers, those expectations happened to be negligible.

Consequently, interviews were conducted on each group of interviewees in the same order where the procedure started with the representatives of Islamic society with a total of ten in number, each interviewed independently. Next to be interviewed were members of Islamic intellectual society, ten representatives in total. Finally, last to be interviewed were representatives of Tariqas, eight representatives.

The first question that was asked and the question that opened the interview were:

What is the current situation of the Tariqas as a part of Islamic society in Macedonia?

All ten representatives of Islamic society gave independently nearly the same answer stating that Tariqas were well accepted. It is regarded as an important and respected element of Islamic society and most of their praxis is included in everyday religious life.

Two interviewees, representatives from Islamic society, had explained that on the territory of Republic of Macedonia, certain religious activities are being performed by few Tariqas among whom are the Bektashi order which are religious activities. Some of them are slightly contrary with the main teaching. Both of the interviewees were not so generous in giving particular explanation on the subject. Another interviewee, representative from Islamic society, gave the explanation on how this group is practicing religious customs not autochthonous for Islam.

As one of the interviewee noted, 'Islam is the religion of the truth, and the truth is based on what is directed inside the holy book, Quran; and this religious group, the part of Bektash order not supported by Islamic society, is practicing a rather not prescribed and sometimes forbidden rituals by the Quran'. 
This question is pretty much intricate having in mind the specific explanation of the last interviewee representing the Islamic society. Thus, an additional question was part of further interviews for detecting the reason for such deviations.

Some of the interviewees representing the Islamic society pointed out how Sufism has been present in this area for centuries. They also show how Tariqas are part of Islam in this region regardless of our consideration.

A common view shared among tenth interviewees, representing the intellectual society, is that Tariqas is an integral part of the Islamic society. One interviewee pointed how Islamic society is showing tolerance for some Sufi rituals that are unusual for popular Islam. In that manner, Islamic society is keeping a low profile.

Another interviewee from the intellectual society, in a rather exhausting and overwhelming explanation in a way incorporates the independent answers from all the representatives of intellectual society, have pointed out this tolerant attitude practiced by Islamic society. However, Islamic society appreciates the Tariqas because it is an extraordinary and charming aspect of Islam in these areas. He further gives explanation how that centuries ago, these areas were places where Tesawwuf were active and these areas have their specific touch in Tesawwuf. Today, it is visible that the Muslims originate from this area, especially during certain encounters with Muslims that are not from these cultural surroundings. However, what is notable for these last decades is the presence of a certain change: a change that tries to influence the Islamic society.

Tariqa representatives, eight in total, while giving the explanation behind the tolerant attitude of the Islamic society noted that Islam is a very old religion which in its genesis has a certain changes. However, it is one of the few religions of today's world that managed to withstand its authenticity; namely, cause of its strict rules on which all Muslims are subjected. One of the interviewees pointed that it is customary for all the Sufis to pay tribute to their shepherds, at the places where their shepherds were buried. Today, all that is being misunderstood. Hence, the picture of this old custom that is present among all Sufi orders is shown to be more like idolatry. In addition, it is directly against the solemn basics of Islam religion. Following that, the interviewee pointed out that this is where the main reason for marginalization tactics against Bektash order can be traced. Based on the sub question, "Was it the Islamic society that performs a marginalization actions against Bektashi order?", the answer was that it is a delicate situation. On the same sub question, next representative of the Tariqa pointed out that in this current situation with the Bektashi order, what is evident is a certain amount of introversion and closeness among themselves. 
One of the interviewees of the Tariqas, a member of Bektashi order, did not give any comment on the sub questions that was considering the Bektashi order, not as much as a facial expression. However, he only gave answer on the written question. This question reveals that the position of the Islamic society in this manner is close to indifference, but just at this moment though.

Are the Tariqas equally treated within Islamic society?

The above question was meant to monitor the treatment of Sufi groups, i.e. its equal treatment as a part of the Islamic society.

The overall attitude of the representatives of the Islamic society was positive, and all the ten interviewees answered that in all the religious institutions considered, the Islamic society welcomes all Muslims.

A representative of Islamic society pointed out that the prayer or namaz, is directed toward accomplishing peace in general, and thus divine peace. At this point, all the ten representatives shared the opinion that Islamic society doesn't make any separation between Muslim followers. Hence, it is accessible to anyone who needs to open up to Allah, and Sufis aren't excluded.

Concerning the treatment given by Islamic society towards Tariqas, there are minor divergences when answers given by the representatives of the intellectual society are summarized and analyzed. All ten representatives have nearly the same answers; they share same thoughts about inclusivity and there is no selectivity at any level shown by Islamic society in communication and general relations with all Muslims including Sufis. Thus, among interviewees, there were insinuating answers that provoked rather intricate sub questions, and this causality action resulted to a particular conversation to expose a shared attitude which set the middle ground on possible initiative insufficiency at the general policy promoted by Islamic society. In other words, the Islamic society should make efforts in more efficient consolidation on the whole member body in general.

All eight members of the Tariqas answered that Islamic society is opened to them. However, one of the interviewee pointed out the same thing that was previously explained by the members of the intellectual society, namely: Islamic society should work in better consolidating activities for Muslim followers in general.

What is the current number of Tariqa followers within Macedonian society?

The interviewees representing the Islamic society didn't come up with the certain number, yet only few interviewees agreed that the current number is very low like 5\% from Muslim member body or even less. Members from the Tariqas that were included in the interview stated that on the territory of the Republic of Macedonia, many Tekkes which were in function are particular Sufi orders. As the biggest region, they mentioned the Polog region where the Bektashi Tekke in Tetovo is situated. This Tekke also have a 
significant influence on nearby regions such as Struga, Debar, Kichevo, Ohrid, and Prilep. Khalwati Tekke has its activities in region of Ohrid and Struga.

One interviewee, representative of Islamic society, stated that in area of Skopje, more specific municipality of Shuto Orizari is located the Rifai Tekke and in the central area of Skopje are located the Sadiyas order.

When asked about the number of Muslim followers, the representatives of the Tariqas all answered similarly as they are few in number. Thus, they all agreed to be like $5 \%$ of the Muslim followers.

A part of the interviewees representing the Islamic society and part of the interviewees representing the intellectual society have pointed out the introvert character of the Tariqas within Macedonian society, and on the Balkan Peninsula as a factor for not knowing the exact number of Sufi followers in the region. It was pointed out by one representative from the intellectual society that the period of transition has influenced the relationship among people in general. Society in general gets encountered by people stuck with sole survival drive. Therefore, when the global social, political and economical situation experience changed, societies became opened for foreign influence. This in return brought a mixed up already mixed things.

\section{How Islamic society oversees Tariqas and Sufism?}

The answers on the question number 4 , given by the representatives of the Islamic society, are nearly the same. It points that Islamic society accepts the teaching of the Tariqas and that this teaching is a part of the Islam religion. One interviewee was clearly saying that Islamic mysticism is an inherent part of Islam and that it was and has always been present here in this area. Thus, Islamic society should not deny its contribution in all what Islam is.

Considering the question above, most precise and at the same, most inclusive answer was given by the representatives of Islamic society. The answers from other interviewees were in complementary coherence.

Detection for possible selective position by Islamic society towards members of Tariqa was an element inside the $5^{\text {th }}$ question from the interview - the last question from this thematic unites that is centered on the relations between Islamic society and Tariqas.

Subsequently, all the interviewees have shown that Islamic society doesn't support any selectiveness in treatment towards any Muslims including the Tariqas. The function of the Islamic society is to collect and incorporate all the Muslim followers under the same roof - as one of the interviewee will explain. He will add here that Sufis are also Muslim followers and they are accepted by the society. Considering this question, we found certain correlations with the answers from the representatives of intellectual society, and the representatives from the Tariqa respectively. What was the same point in these answers is that Islamic society doesn't support any selectiveness regarding its followers. 
The second thematic unit of questions was meant to detect the level of affirmation of Sufism inside Macedonian society. By this thematic unit of questions, we seek to encircle and thus monitor the presence of Sufism inside Macedonian society. In addition, we also aim to create awareness of the citizens in general with cultural dimensions of Sufism and its potential benefits. Part of the questions is directed towards projection of the potential benefit of the Sufi culture in further reinforcement of the balance between cultural and religious diversity. Other part of the questions is directed in investigating the cultural and religious integration within Macedonian society mostly, but in anticipating the wider region.

What are the relations between Tariqas and other religious groups inside Macedonian society?

The question under number 6 listed above, representatives from Islamic society, didn't give strict answers. Therefore, what was in common was the expression of positivity while describing this relationship. One of the interviewee pointed out that Tariqas are more introvert in their public religious activities, without giving reasons for this low profile activity. Other interviewee pointed out that he never heard anything else but compliments describing the relations between Tariqas and other religious groups in the wider area of Balkans.

Analyzing the relation with other religious groups, most of the interviewees representing the intellectual society pointed out that Tariqas for decades have now positioned themselves in rather closed introvert position. In general, they are not exposed with global social currents. Due to this situation, the interviewees mostly traced the previous political situation in the region. One of the interviewee representing the intellectual society explained how there was moments when this closeness did paid awhile like overcoming important existential circumstances. These moments were usually referred to as a religious transition by scholars. Anticipating all that, what is needed here is a certain period of time for returning back the trust and confidence among all the social elements. "What we're talking about could be a period of reknowing each other" - is what interviewee said.

The representatives of the Tariqas that were interviewed expressed a common thought describing the basis of Tesawwuf which is a mutual and respectful coexistence among each man. Although this is basically the same answer given by all eight representatives of the Tariqas, one interviewee gave a rather interesting explanation: "It's in the core of Tesawwuf based on the mutual understanding and compassion among people and this is why all the differences and diversities are being accepted as a treasury rather than a challenge, and what is the ideological basis of Tesawwuf? it's Islam".

How would you explain relatively weak affirmation of Sufism in Macedonian society? 
While answering the question considering the affirmation of Sufism in Macedonian society, one interviewee representing the Islamic society pointed out that Muslims have their religious life completely covered by Islamic society. However, Islamic community is completely dedicated to every religious aspect on which all Muslims are subjected. Almost the same answer was given by others interviewees representatives of Islamic society, although one interviewee gave a significant answer. This interviewee pointed out that in the last decades, the first moments of independence. This was the time before it was a characteristically low level of improvement in various cultural aspects of this society in general. As a consequence of this situation of ignorance, in a case, it is reflected as a marginalization of a number of elements which have played constructive role for this society ages ago. A few interviewees representing the Intellectual society explained how Macedonian society was supposed to recognize those cultural aspects in the early days and moments of creation of the modern Macedonian state. Thus, this is because at the end, what we see today is only a fraction of what needs to be seen as a whole considering the Macedonian society. In tracing the problem for this situation, most of the answers have found a middle ground in people's interest. This means that based on their nature, Tariqas are closed for the general public. They are like mini organizations which made their affirmation in a direct correlation with the way they perform their religious rituals etc. As a part of Islamic society in Macedonia, Tariqas are equally treated and preserved in their original form. When further questioned about where the Islamic society undertakes some activities in Tariqa's cultural affirmation - the answer was negative. The representatives of Tariqas pointed out that the current situation of Macedonian society is crisis. One of Tariqa's representatives explained that the Republic of Macedonia as a country and as a society respectively is still under transition. This is a process that might have a significant effect on the whole, and some parts of the social life were deeply affected. Overall, the whole society is under crisis. In addition, a lot of things that are with existential importance are not well represented in our society. Such case is the current situation with the Tariqas. Macedonian society doesn't have the slightest notion considering the Tariqas and Tesawwuf. Therefore, the constitution affects both Christians as well as Muslims.

Is the activity of Tariqas in Macedonian society to be considered latent and if so, what are the reasons for such latency?

Considering the question number 8 , part of the representatives of Islamic society explained that there is a certain correlation among some of the rituals performed by Tariqas that are closed for general public. This is having in mind the Dervish orders that are not completely backed up by Islamic society but are tolerated. 
Some of the representatives of the Intellectual society argued how Tarikas are closed orders in general aspect, has their place within Islamic society, and how their actions are prescribed by certain strict rules and through which all followers are subjected. Also, there are a variety of customs and rituals that are exclusively Sufi in nature and are strictly dedicated to members of Tariqas.

Tariqa representatives, a part of them answered that Tesawwuf and the Tariqas are not well represented and all the activities remain strictly within what is known as a few folklore gatherings. This isn't just a thing to blame Tariqas, but the whole society. This is because Tariqa and Tesawuff aren't only a doctrinaire thing, but are cultural, phenomenological, educational etc. So the values of Tariqa and Tesawwuf should be a thing of interest for all institutions that are dealing with this matter. society?

Is the Tariqas subject for stereotypes within Macedonian

Representatives from Islamic society answered that there are no such thing like stereotypes, considering the Tariqa orders inside the Macedonian society. More to say, Islamic society acts in a way not to provoke any sort of discrimination or prejudicial actions when considering the Tariqas or wider membership.

Similar answers were given by the representatives of the Intellectual society where one interviewee explained how Tariqas are closed in their religious actions. Nevertheless, that is how they act and not as a result of some stereotypes or discriminatory policies conducted by Islamic society or someone else.

One of the representatives of the Tariqas explained how not knowing the Tesawwuf in general have a consequential stereotypical praxis.

The Tariqas within Macedonian society, are they opened

for just a certain group of citizens having certain ethnicity?

Chattering about the actual position of the Tariqas with the rest social elements in Macedonian society, representatives of the Islamic society clarified that Tariqas are in general opened towards all social factors and social elements. One of the interviewees pointed out that by having in mind the nature of Tesawwuf, Tariqas are directed towards man, people in general. Therefore, this is not only an element of Tesawwuf but of Islam in general. This is because the Holy Quran is the last divine word that was passed by the Prophet with a mission to teach people on mutual understanding.

Another interviewee explained the openness of Islam towards the world and minding that not only Tesawwuf, but Islam as a whole, is a core opened and inclusive religion.

Representative of the Tariqas will clarify that Sufism in its teachings opens the secrets in front of the people, thus attending to express that there is 
no such thing as invisible. Therefore, man is not in power to see the Sufi parole centering the divine presence at every action of man, whether it's a mindful or physical action.

Representatives of the Intellectual society have their answers pointed at the same conclusion that was expressed by the representatives of the Tariqas.

\section{How is Sufism represented inside Macedonian society?}

Searching to understand the position of Sufism inside Macedonian society has directed the survey to the point where most of the answers from the interviewees were concluding based on nearly the same idea. That idea was the sole basis of the Sufism and its intrinsic human dimension.

When describing the Sufism within Islam, interviewees representing the Islamic society explained how that it is a bit similar with the Protestants within Christianity. Sufis emit their wisdom directly towards human mutual understanding and respect. That is why Tesawwuf is a bit closer to the modern man, having modern considerations, and a man that is not completely dedicated to the religious jurisprudence and yet is a man of faith. This expression has a similarity with the answers given by representatives of the Intellectual society. Also, they will add that modern man caught inside modern current will be much easier to approach the cultural works that penetrate the subject of Tesawwuf - like the example with Rumi Mevlana, when compared with the distinctive principles of the Sharia law.

One of the representatives of the Intellectual society argued how Tesawwuf was constructed by strict rules. Yet for the sake of modernity workings of the Sufi saints, the Sufi literature, writings, poems etc where wisdom and morality are the subject are more accessible by contemporary people.

Representatives of the Tariqas pointed out how Sufism is on low level of presence in what is to be a public social life. And even at this low level of presence, it comes with a lot of defects and misunderstandings of the essence. One of the interviewees explained that the Macedonian man mostly have some notion about Sufism through the workings of Mevlana Rumi as the most accessible. This is together with some similar Sufi authors mainly from France. However, all of this is pretty much below what Tesawwuf has potential for, having in mind here the positive examples with United States.

\section{Despite the enormous affirmation that Sufis achieved}

inside US and Europe, why is Sufism unknown within Macedonian society?

Locating the reasons for such positioning of Sufism within Macedonian society, representatives from the Islamic society explained how the general membership of the Islamic society has their religious needs fully accommodated inside the Islamic Society of the Republic of Macedonia. 
Sufism inside US is well supported, thanks to recognition of a similar Protestant tradition that keeps the religious life as individual matter what means. Also, it further explains the representative from Intellectual society: "people can perform their religion within the privacy of their home with their relatives, close friends, and what happens in public life is more reserve and settle approach regarding the subject of religiosity. Hence, this is one option that leads to individualization of religion experience, an experience that should be more individual than collective".

Most of the representatives of the Tariqas had a similar explanation how Sufism represents the spiritual side of the faith and modern man that is overloaded with consumerism as a way of life. As a result, there is an important need for this spiritual enlightenment. That is the reason why Sufism is more analyzed by Western scholars. Situation with Macedonian society, sublimating the expressions of one interviewee will continue, "sadly, but Macedonian society just can't get off this constant transitional vortex and this is why we don't have time for much needed and valuable things in our lives".

All interviewees were questioned about the attitude of the contemporary Macedonian society considering the Tariqas. Also, the representatives of the Intellectual society commented that this society is in an endless cycle of transition. In addition, these elements of Sufism just passes by like totally, and are not perceived by citizens. Another representative of the Islamic society pointed out that the terminology "Sufism" in Islam is something equal and is the same thing. Thus, this is the same case with those who've heard a thing or two for Sufism.

What is the general attitude of the contemporary

Macedonian society regarding Tariqas with anticipation on

low acquaintance with the subject of Sufism?

Few of the representatives of the Intellectual society explained how with these days modern world situation, following the Western society's quest for spirituality, has entered into our neighborhood also. Similar with the Western societies, our society aims for a better life and for quality life, and that's exactly the virtue of Tesawwuf. Having this attitude, spiritual awakening and investment in spiritual development, the intention is to increase the quality of life.

Pretty much interesting was the answer given by some of the interviewees pointing out that Sufism when closely examined is a little odd for average people. Hence, what was added by the representatives of the Tariqas is that older citizens, mostly artisans and trades people, recognize what Sufism have within its teaching as once authentic and rather a unique trait of the oriental Islam religion. With this answer given by the representatives of Islamic society, we can go along the answers of the representatives of the Tariqas. Subsequently, one of the interviewees of the Tariqas added how the 
older families that have grown in this authentic intercultural settlement of the twenty century or before have a notion about this aspect of Islam religion.

Were there some obstacles considering the religious

activities of the Sufi groups within Macedonian society and its cultural development?

Representatives of the Islamic society agreed with their answers that there is no such thing as obstacles in religious activities of the Tariqas inside Macedonian society and its cultural development. One representative will explain how Islamic society doesn't argue with most inherent elements of Sufi tradition within Islam religion. Thus, they were given enough freedom with their praxis.

Representatives of the Intellectual society explained how some sort of activity plan mainly performed by the government authorities and public institutions is needed so that it could be supported by the cultural elements of Sufi tradition which isn't something new in this area. The answers of the Tariqa's representatives are similar to this explanation. One of the interviewees of the Tariqas will add to this that obstacles were not reported and there is no such thing as a support.

Should Tariqas act towards increasing their efforts in

potential enhancement of cultural integrations?

Representatives of the Islamic society explained how this society represents unrestricted support for all religious needs of its followers including the needs for certain affirmation etc. The only limit that is present is time and finances. This is so that Islamic society doesn't restrict if Tariqas do something on their affirmation within our society.

Part of the representatives of the Intellectual society pointed out how there is a situation of different opinions within Tariqas in Macedonia. Thus, this situation isn't something new for us because it was present also in near history. On the sub question to give a more strict explanation on this situation, one representative of the Intellectual society will explain that there is a history of pondering in regards to attitudes within Tariqas in Macedonia. Another interviewee from the Intellectual society will explain this situation with long tradition of strict and heavy polarized political duality that reflects in social and cultural life for a long time.

One of the interviewees representing the Intellectual society will point out how Macedonian society should define its goal that will have a rather unification effect. Hence, this move is needed especially from the Tariqas that are a part of the society. Additionally, it is natural to have a mutual interference between Tariqas and Macedonian society.

Similar observation was given by the representatives of the Tariqas, where one interviewee will explain pretty vividly that Tariqas should unite among themselves in the first place. Thus, this would help them to represent 
Sufism as it should and then promote all the cultural delicates of the Tesawwuf.

$$
\text { Could some parts of the Sufism be a part of the }
$$

Macedonian everyday life?

Representatives from the Islamic society will explain that substantial part from the Islam religion is part from the everyday life in Macedonian society. Some of the interviewees explained this for years and decades before there was some praxis to minimize this centuries old tradition in interaction on Balkan Peninsula. However, western culture did teach us that what we are emphasizing here isn't jus Sufism or Islam or just Christianity - Orthodoxy, but all forms of interaction between people having their own cultural traits in these areas. This is the true treasure, and Sufism has the potential to be its authentic mark.

Representative from the Intellectual society explained how elements of Sufism are not only are substantial in Western societies, but are also dealing with rising aspirations by common people. As a result, this situation will get us because the message of Sufism will point out the interviewee: "the very basis of the Sufism are the elementary human characteristics: Love, Respect, and Community".

Similar expression was given by the representatives of the Tariqas, meaning that there are elements from Sufism that are part of everyday life. However, the potential of Sufism can offer more.

Is Sufism capable of creating a religious and cultural

balance within Macedonian society?

Representative from the Islamic society will explain that Sufism and Islam in general are directed towards religious and cultural integration and for example there are various historical situations like the Prophet Isa that is present in Christianity and also in Islam. So the potential for cultural integration was preset and is still present, but it is up to us how we will use it.

Representative from the Intellectual society will explain that Sufism has big potential for cultural integration. Sufism is something similar to what Protestants are inside Christianity. Sufism has more relaxed approach for the followers and people in general speaking from cultural aspect and from religious aspect there are certain rules that are necessary to be followed by the believers. But the thing that touches wide popular masses is the workings from the great Sufi teachers with the message that is sent to the all people for mutual and unconditioned love and respect among each other. Other representatives from the group share this view.

Representative from the Tariqas will explain: "Tesawwuf at the same time is a cultural consolidation of the whole society and with ages inside Tariqa circles are cultivated numerous elements of mutual art and culture. Yes, of course." 
Other representatives from the Tariqas gave similar answers.

Do you think that Sufism could bring relief and integration considering the religious and cultural relations within Macedonian society, closely as it is the case with USA?

Representatives from the Islamic society all agreed that Sufism as a part of Islam has the potential to contribute in this manner.

A representative from the Intellectual society described how world examples, namely USA, have recognized that potential and that is the reason why they invest in that policy.

Some interviewees from the Intellectual society gave similar answers with the representatives from the Islamic society and explained that Islam is a religion that aims for balanced relations in general among all people in every aspect of their social life.

Confirmed answer was also given by the representatives of the Tariqas, explaining how Sufi teaching can bring balance and mutual understanding in Macedonian society.

Will it be useful if Macedonian society take some specific actions in better affirmation on Sufism, as for example the case with USA?

Representatives from the Islamic society gave pretty reserved answers for this particular question. This was in a way expected to mind the previous answers which in most occasions placed Sufism and Islam on the scale.

Some of the interviewees representing the Islamic society explained that through this way, every man will be more useful to the whole society. Islam has a lot of cultural elements that brings the message of mutual coexistence, personal and social affinities, and also a simulative approach for constructive interpersonal relations. And speaking in this manner, Tesawwuf is part of Islam. Certainly, its affirmation from cultural aspect, in rather refined aspect, would be highly beneficial to this society.

Interviewee from the Intellectual society will point out how USA entered the policy of glocalization with a few tactical moves among which Sufism stands as a very exceptional protagonist. He will add: "We are not seeking who is the brightest or smartest, that is only a situation of a circumstances where the practical mind has its lead in every aspect of what is known as a social sphere. What follows here is a transition from multiculturalism into interculturalism and that is a process that has affected the whole region".

This is similar to the answer from another interviewee representing the Intellectual society who represented Sufism as extremely important moment whose integrative potential was recognized by Western societies.

Representatives from the Tariqas explained that such policy would be very fruitful for Macedonian society. 
What measurements would you recommend for the cultural subject that would have resulted in better affirmation of Sufism within Macedonian society?

Most representatives from the Intellectual society explained that most important that should be done at this very moment by the cultural institutions would be substantial efforts in preserving the Sufi objects, buildings that are in much deteriorated condition. Also, another representative will add that published cultural material from distinguished Sufi writers should be increased.

Interviewee representing the Tariqas explained: "In my opinion, the state should take very seriously the phenomenon of religion and its social role. Then, of course, that should be done with more efforts in further translating and publishing of the workings of distinguished Sufi writers as is the case of Mevlana Rumi; in this manner, we could take the example of Western societies, presentation of cultural elements of Tesawwuf within society in general, etc.".

Observing Islam from one side, it is quite obvious that it is the Islamic law or Sharia that creates the first impression about Islam as a religion. Hence, this is a bit different from other Abraham religions.

\section{Conclusion}

Islam religion has its specific charm that was built in centuries during the Ottoman Empire, and it has its influence on Balkan Peninsula. As an Empire's religion, Sufism has its duty to affect all the various nationalities and religions that were then present in the region and to act as a peace promoter in the region. The potential of cultural integration is evident in every aspect of Sufism, beginning from its base premise which is divine love. This potential was detected by the US State Department on which was created US foreign policy in the wider region of the Middle East.

Macedonian society has a long history of wide multicultural relations. This is a social network built by vast variety of nations, nationalities, and religious varieties. Nevertheless, the late history of the Macedonian society was the antireligious influence emitted by the previous communist regime that has its effect more or less in the mess that was evident in latter process of transition. As time progresses, people in their masses returned their religious beliefs as it was in the days before the communist regime. Thus, in these moments of religious renaissance, there were Islamic currents originating from Middle East that propagated the thought in a way that is a bit different from what was known among the older generation. Their accent was directed towards a fraction of what is Islam in its comprehensiveness. This fraction is known as Al Islam and it means the religious praxis. Thus, this is the second level of the fate and is occupied with the righteous way in practicing the 
religion directed to achieve complete awareness of the murid. This was such that every aspect of the religious life has a strictly prescribed way on how to be practiced. What is notable within Macedonian society, mostly within older generation, is in having a little different way of practicing the Islam religion. Islam praxis is not so evident. Yes, it is present but its awareness is on higher level. Communication with older generation Muslims is more directed on wise thoughts. It involves telling stories of great wisdom without pointing directly on mutual interreligious tolerance, but latently pointing on human coexistence. Hence, a member of the Tariqa will say, "that is the charm that Sufism gave in this region."

\section{References:}

1. Almazova Leyla (2014). Islam in Multicultural World: Muslim movements and Mechanisms of reproduction Ideology of Islam in the modern Information space. Kazan: University of Kazan. (154-253).

2. Baran Zeyno (2004). Understanding Sufism and its Potential Role in US Policy. Washington: The Nixon Center. (16-22).

3. Beglerovic, S. (2004). Ka psihoterapiji sufizma. Znaci, Februar 6,

4. https://znaci.com/osnovi_vjerovanja/tesavvuf/art310_0.html.

5. Beyer Peter (2007). Religion, Globalization and Culture. Leiden: Koninklijke Brill NV. (167-87; 335-355).

6. Boyce, C. \& Neale, P. (2006). Conducting In-Depth Interviews: A Guide for Designing and Conducting In-Depth Interviews for Evaluation Input. Watertown: Pathfinder International.

7. Casanova Jose (2004). Religion, Secular Identities, and European Integration. Transit 27 (07-2004). www.iwm.at/r-reflec.htm

8. Corbin Henry (1962). History of Islamic Philosophy. London: Kegan Paul International. (187-99).

9. Faghfoory Mohammad (2003). Kernel of the Kernel: $\mathrm{A} \mathrm{Sh}^{-}{ }^{-}{ }^{-}$ Approach to Sufism. New York: State University of New York Press.(83-127).

10. Geaves Ron, Dressler Markus \& Klinkhammer Grit (2009). Sufis in Western Society: Global networking and locality. New York: Routledge. (47-172).

11. Geertz, Clifford (1973). The Interpretation of Cultures. New York: Basic Books, Inc., Publishers. (87-126).

12. Hodgson, G. \& Marshall, S. (1993). Rethinking World History: Essays on Europe, Islam and World History. Cambridge: Cambridge University Press. (97-207).

13. Karamustafa, A. T. (2007). Sufism: The formative period. Edinburg: Edinburg University Press. 
14. Schirrmacher Christine (2008). Islam and Society. Bonn: Verlag fur Kultur und Wissenschaft, Culture and Science Publ.(7-67). 